\title{
PENGARUH KEHILANGAN GIGI POSTERIOR TERHADAP KUALITAS HIDUP INDIVIDU LANJUT USIA STUDI TERHADAP INDIVIDU LANJUT USIA DI UNIT REHABILITASI SOSIAL PUCANG GADING DAN PANTI WREDHA HARAPAN IBU SEMARANG
}

\author{
Gilang Satria Wardhana*, Moh.Baehaqi*, Rizki Amalina*
}

Keywords:

Elderly, Quality of life posterior tooth loss

\section{ABSTRACT}

Background: Elderly is an individual who has reached the age of 60 years and above. The aging process causes changes in the physical condition of the individual and affect the structure of the oral cavity includes the function of teeth, jaws and other oral tissues. Loss of teeth leads to reduced ability to chew, bite, talk and decrease a person's confidence. Quality of life is the individual response to physical function, psychological and social to their everyday lives. Oral Health Related Quality of Life can be measured by several kinds of questionnaires, one of them is OHIP - 14. Purpose: The aim of this study are to determine impact of losing posterior teeth on quality of life on elderly individuals between tooth loss $<3$ posterior teeth with tooth loss $\geq 3$ posterior teeth in an arch. Method: The research method was analytic observational cross-sectional approach. The sample in this study were 40 individuals who were divided into two groups, group A elderly individuals with posterior tooth loss $<3$ in one arch and group B elderly individuals with posterior tooth loss $\geq$ 3 in one arch. Analysis of the data in this study was using a non-parametric test with Kolmogorov -Smirnov test with $p<0.05$. Result: Based on the Kolmogorov -Smirnov test, concluded there are significant differences between groups $A$ and group $B(p<0.05)$. Conclusion: From the results of this study concluded that elderly individuals with posterior tooth loss $<3$ in the arch have a better quality of life. Group b elderly individuals with posterior tooth loss $\geq 3$ in the arch have a lower quality of life.

\section{PENDAHULUAN}

Lanjut usia adalah seorang laki-laki atau perempuan yang berusia 60 tahun atau lebih, baik yang secara fisik berkemampuan (potensial) maupun karena suatu hal sehingga menyebabkan lanjut usia tidak lagi berperan aktif dalam pembangunan (tidak potensial) 1. Pengelompokkan usia menggunakan pembagian menurut WHO, dengan usia 45-60 tahun (middle age), usia 60-75 tahun (elderly), usia 75-90 tahun (old), usia diatas 90 tahun (very old) ${ }^{2}$.

Kualitas hidup adalah respon individu terhadap kehidupannya sehari-hari terhadap fungsi fisik, psikis, dan sosial mereka ${ }^{3}$. Kualitas hidup lanjut usia yang berkualitas didukung oleh kondisi fungsional lanjut usia yang optimal sehingga yang bersangkutan dapat menikmati masa tuanya dengan bermakna, bahagia dan berguna ${ }^{4}$. Menua (menjadi tua) adalah suatu proses menurunnya kemampuan jaringan untuk memperbaiki diri / mengganti dan mempertahankan fungsi normalnya sehingga tidak dapat bertahan terhadap infeksi dan memperbaiki kerusakan yang diderita ${ }^{5}$.

Penuaan menurut kamus kedokteran Dorland adalah perubahan struktural yang bertahap, muncul seiring berjalannya waktu yang tidak disebabkan oleh penyakit atau kecelakaan dan akhirnya meningkatkan kemungkinan kematian bagi organisme akibat menjadi tua. Banyak perubahan yang terjadi dalam proses penuaan yang dapat *Program Pendidikan Dokter Gigi Fakultas Kedokteran Gigi Unissula Semarang, ** Staff Pengajar Fakultas Kedokteran Gigi Universitas Islam Sultan Agung Semarang Korespondensi : gilang.es.we@gmail.com 
mempengaruhi struktur rongga mulut yaitu perubahan struktur dan fungsi gigi, rahang, dan jaringan mulut lainnya ${ }^{6}$.

Kehilangan gigi yang dibiarkan terlalu lama akan menyebabkan migrasi patologis gigigeligi yang tersisa, penurunan tulang alveolar pada daerah yang edentulous, penurunan fungsi pengunyahan hingga gangguan berbicara dan juga dapat berpengaruh terhadap sendi temporomandibular. Karena idealnya oklusi yang baik harus memungkinkan mandibula bertranslasi tanpa hambatan oklusal saat terjadi gerakan fungsional terutama pada segmen posterior sehingga distribusi beban lebih merata ${ }^{7,8}$. Kehilangan gigi lebih dari 3 gigi posterior dalam satu lengkung rahang dapat mengganggu sistem mastikasi ${ }^{9}$. Permasalahan kesehatan umum dan gigi-mulut dapat mempengaruhi kualitas hidup individu lanjut usia ${ }^{10}$.

Pendekatan klinis sudah lama dipakai untuk menilai kesehatan rongga mulut seseorang, namun pendekatan klinis bersifat terbatas dan tidak dapat dipertimbangkan dari aspek fungsional dan psikososial kesehatan gigi dan mulut. Telah dikembangkan berbagai cara untuk mengukur Oral Health Related Quality of Life (OHRQoL) untuk menggambarkan dampak kesehatan mulut pada pasien.11 Salah satunya yaitu Oral Health Impact Profile-14 (OHIP-14), yang mencakup 14 pertanyaan tentang keterbatasan fungsi, sakit atau nyeri, ketidaknyamanan psikologis, gangguan psikologis, gangguan sosial dan handicap. OHIP-14 adalah versi yang lebih ringkas dari 49 pertanyaan OHIP yang dikembangkan oleh Locker D tahun 1988. Geriatric Oral Health Assessment Index yang dikembangkan oleh Atchinson dan Dolan tahun 1990 sebagai General Oral Health Assessment Index.

\section{METODE PENELITIAN}

Jenis penelitian yang digunakan merupakan jenis penelitian observasional analitik dengan pendekatan cross-sectional. Populasi yang digunakan dalam penelitian ini adalah individu lanjut usia yang tinggal di Unit Rehabilitasi Sosial Pucang Gading dan Panti Wredha Harapan Ibu Ngaliyan Semarang dengan jumlah sampel 40 orang yang terbagi dalam 2 kelompok yaitu kelompok $A$ individu lanjut usia dengan kehilangan gigi posterior < 3 dalam satu lengkung rahang dan kelompok $B$ individu lanjut usia dengan kehilangan gigi posterior $\geq 3$ dalam satu lengkung rahang. Variabel bebas dalam penelitian ini adalah kehilangan gigi posterior, variable terikatnya adalah kualitas hidup individu lanjut usia.

Kehilangan gigi yang dimaksud adalah kehilangan gigi posterior dan gigi yang diindikasikan dicabut atau tidak dapat direstorasi. Jumlah kehilangan gigi $\geq 3$ gigi posterior dalam satu lengkung rahang dengan skala pengukuran interval.

Kualitas hidup adalah kualitas hidup yang berhubungan dengan kesehatan rongga mulut yang sebagai akibat dari kehilangan gigi posterior yang mempengaruhi fungsi fisik dan kondisi psikologis yang diukur dengan OHIP-14 dengan skala pengukuran ordinal.

Analisis data menggunakan Chi-Square dalam tabel $2 \times 3$ untuk mengetahui hubungan antara kehilangan gigi posterior terhadap kualitas hidup. Bila tidak memenuhi syarat uji Chi-Square akan dilanjutkan pengujian menggunakan uji Kolmogorov Smirnov. Tingkat kepercayaan pada penelitian ini adalah 95\%.

\section{HASIL PENELITIAN}

Penelitian ini dilakukan di Unit Rehabilitasi Sosial Pucang Gading dan Panti Wredha Harapan Ibu dengan jumlah sampel 40 individu. Penyebaran subjek individu menurut umur dan jenis kelamin tersaji dalam tabel berikut ini. 
Tabel 1. Distribusi Umur

\begin{tabular}{lcc}
\hline Umur (tahun) & $\begin{array}{c}\text { Kehilangan Gigi Posterior < 3 gigi } \\
\text { posterior dan } \geq 3 \text { gigi posterior }\end{array}$ & Persentase \\
\hline $\begin{array}{lcc}\text { Lanjut Usia (60- } \\
75)\end{array}$ & 28 & $70 \%$ \\
\hline $\begin{array}{l}\text { Lanjut Usia Tua } \\
(75-90)\end{array}$ & 12 & $30 \%$ \\
\hline $\begin{array}{l}\text { Lanjut Usia } \\
\text { Sangat Tua } \\
(>90)\end{array}$ & - & - \\
\hline Total & 40 & $100 \%$ \\
\hline
\end{tabular}

Tabel 2. Distribusi Jenis Kelamin

\begin{tabular}{lcc}
\hline $\begin{array}{c}\text { Jenis } \\
\text { Kelamin }\end{array}$ & $\begin{array}{c}\text { Kehilangan Gigi Posterior < 3 gigi } \\
\text { posterior dan } \geq 3 \text { gigi posterior }\end{array}$ & Persentase \\
\hline Laki-laki & 12 & $30 \%$ \\
\hline Perempuan & 28 & $70 \%$ \\
\hline Total & 40 & $100 \%$ \\
\hline
\end{tabular}

Dari tabel 1 menunjukkan bahwa sebagian besar sampel penelitian merupakan kelompok lanjut usia (elderly) 60-75 tahun sebanyak 28 individu dengan persentase sebesar $70 \%$, sedangkan dari tabel 2 distribusi sampel berdasarkan jenis kelamin sebagian besar individu penelitian adalah perempuan yaitu 28 individu dengan persentase sebesar $70 \%$.

Untuk mengetahui pengaruh kehilanagn gigi posterior terhadap kehilangan gigi dilakukan analisis Kolmogorov-Smirnov dengan hasil sebagai berikut.

Tabel 3. Hasil analisis kehilangan gigi posterior dengan kualitas hidup yang berhubungan dengan kesehatan rongga mulut menggunakan uji Kolmogorof-Smirnov

\begin{tabular}{ccc}
\hline $\begin{array}{c}\text { Kehilangan gigi } \\
\text { posterior }\end{array}$ & Total sampel (n) & $P$ \\
\hline$<3$ gigi posterior & 20 & 0,001 \\
\hline$\geq 3$ gigi posterior & 20 & \\
\hline
\end{tabular}

Dari hasil analisis kualitas hidup yang berhubungan dengan kesehatan rongga mulut dengan uji Kolmogorof-Smirnov menunjukkan nilai yang $p<0,05$ maka dapat diambil kesimpulan bahwa terdapat perbedaan yang bermakna antara kelompok individu lanjut usia dengan kehilangan $<3$ gigi posterior dan individu lanjut usia dengan kehilangan $\geq 3$ gigi posterior dalam satu lengkung rahang.

\section{DISKUSI}

Pada penelitian ini, jumlah sampel individu lanjut usia yang memiliki kehilangan gigi lebih banyak pada usia 60-75 tahun atau pada kategori lanjut usia sebesar $70 \%$, daripada usia 75-90 tahun lebih sedikit yaitu sebesar $30 \%$, dan pada usia $>90$ tahun tidak ditemukan. Hal ini dikarenakan usia harapan hidup individu lanjut usia di Indonesia ada dikisaran usia 70,2 tahun ${ }^{12}$. Dari distribusi jenis kelamin, persentase kehilangan gigi lebih banyak pada perempuan yaitu sebesar $70 \%$, sedangkan pada laki-laki sebesar $30 \%$. Dilihat dari jenis kelamin lanjut usia yang paling banyak di Indonesia adalah berjenis kelamin perempuan dengan persentase $8,2 \%$ sedangkan laki-laki $6,9 \%$, sehingga akan lebih mudah menemukan individu lanjut usia berjenis kelamin perempuan daripada individu lanjut usia laki-laki ${ }^{13}$.

Individu lanjut usia yang memiliki kehilangan gigi posterior $\geq 3$ gigi posterior menyebabkan kesulitan berbicara. Penelitian 
sebelumnya menyebutkan untuk mengucapkan beberapa huruf konsonan tertentu diperlukan lateral seal yang dihasilkan oleh sisi dorsum lidah yang berkontak dengan gigi posterior 14. Seseorang yang memiliki kehilangan gigi posterior yang banyak dapat menyebabkan rasa percaya diri seseorang hilang dan menutup mulut mereka ketika berbicara dengan orang lain ${ }^{15}$

Pada dimensi rasa sakit fisik menunjukkan bahwa individu lanjut usia dengan kehilangan gigi $\geq 3$ gigi posterior cenderung untuk memilih makanan yang lebih lembut karena kesulitan saat makan makanan yang keras dan bila dipaksakan akan menyebabkan rasa sakit pada rongga mulut mereka. Hal ini didukung oleh penelitian sebelumnya yang menyatakan bahwa individu yang mempunyai kehilangan gigi posterior di beberapa kuadran memiliki prevalensi tinggi terkena Temporo Mandibular Disorder ${ }^{16}$. Oklusi yang baik harus memungkinkan mandibula bertranslasi tanpa hambatan oklusal saat gerakan fungsional terutama pada segmen posterior, sehingga efisiensi sisi kerja tidak hilang dan distribusi beban lebih merata ${ }^{7}$.

Gangguan fisik pada individu lanjut usia yang memiliki kehilangan gigi posterior $\geq 3$ gigi posterior akan mempersulit proses pengunyahan dan beberapa merasa tidak puas ketika makan. Hal ini didukung oleh penelitian sebelumnya yang menyatakan bahwa jika regio gigi premolar dan sedikitnya satu gigi molar masih berkontak maka tidak mempengaruhi proses pengunyahan ${ }^{17}$. Proses pengunyahan akan terganggu jika terdapat pengurangan jumlah gigi premolar dan atau molar yang berkontak, dan hal tersebut juga dapat mempengaruhi perubahan dalam pemilihan makanan. Kehilangan gigi mempengaruhi individu lanjut usia memilih makanan, sehingga pamasukan nutrisi akan berkurang dan berlanjut menjadi defisiensi yang dapat mempengaruhi kesehatan umum ${ }^{3}$.

Beberapa individu lanjut usia dengan kehilangan gigi $\geq 3$ gigi posterior akan merasa malu dan merasa kesulitan untuk bersantai serta menyebabkan gangguan psikis. Penilaian individu yang rendah akibat kurangnya asupan makanan yang bisa mereka makan dan rendahnya keyakinan mereka akan keadaan kehilangan gigi mereka dapat menyebabkan depresi ${ }^{15}$. Dari faktor estetik wajah kehilangan gigi premolar akan menyebabkan warna gelap pada daerah bukal ${ }^{18}$.Faktor estetika yang terganggu dapat berakibat pada emosional seseorang dan menyebabkan stress ${ }^{19}$.

Gangguan sosial pada individu lanjut usia dengan kehilangan gigi $\geq 3$ gigi posterior akan cenderung mudah merasa minder dan terganggu dalam melakukan perannya di masyarakat. Gangguan psikis pada beberapa individu lanjut usia akan timbul jika memlikik kehilangan gigi yang banyak karena hal tersebut dapat menyebabkan kecemasan dan kesulitan untuk bersantai. Penelitian sebelumnya mengatakan kehilangan gigi premolar juga dapat menurunkan kualitas hidup lanjut usia yang mempengaruhi kondsi sosial dan psikologis individu ${ }^{20}$.

Handicap atau keterbatasan akibat gangguan pada individu lanjut usia akan timbul ketika memiliki kehilangan gigi $\geq 3$ gigi posterior karena dapat mempengaruhi pengunyahan mereka namun beberapa individu merasa hidupnya puas meski memiliki kehilangan gigi yang banyak. Kehilngan gigi yang banyak akan berdampak pada keterbatasan fungsi mastikasi dan ketidaknyamanan fisik sebagai pemicu penurunan kualitas hidup ${ }^{21}$. Penelitian sebelumnya yang menyatakan bahwa kehilangan gigi lebih dari 3 gigi posterior akan mengganggu sistem mastikasi ${ }^{9}$.

Berdasarkan hasil analisis kehilangan gigi posterior dengan kualitas hidup yang berhubungan dengan kesehatan rongga mulut menggunakan uji Kolmogorof-Smirnov terdapat perbedaan yang bermakna antara individu lanjut usia dengan kehilangan $<3$ gigi posterior dengan individu lanjut usia dengan kehilangan $\geq 3$ gigi posterior. Individu lanjut usia dengan kehilangan $<3$ gigi posterior memiliki kemungkinan yang kecil terjadinya penurunan kualitas hidup yang berhubungan dengan kesehatan rongga mulut, sedangkan individu lanjut usia dengan kehilangan $\geq 3$ gigi posterior memiliki kemungkinan yang besar terjadinya penurunan kualitas hidup yang berhubungan 
dengan kesehatan rongga mulut. Hal ini didukung oleh penelitian sebelumnya yang menyatakan bahwa untuk mastikasi yang baik memerlukan dukungan sepasang premolar dan dua pasang molar yang saling berkontak atau sedikitnya tiga pasang gigi posterior ${ }^{22}$. Kualitas hidup yang berhubungan dengan rongga mulut seorang individu akan dipengaruhi oleh berapa banyak gigi yang saling berkontak atau beroklusi ${ }^{23}$.

\section{KESIMPULAN}

1. Individu lanjut usia dengan kehilangan gigi $<3$ gigi posterior memiliki kualitas hidup yang baik.

2. Individu lanjut usia dengan kehilangan gigi $\geq 3$ gigi posterior memiliki kualitas hidup sedang hingga buruk.

3. Individu lanjut usia dengan kehilangan gigi < 3 gigi posterior tidak mengalami gangguan, keterbatasan maupun rasa sakit pada fungsi dari rongga mulut maupun gigi geliginya sedangkan rata-rata individu lanjut usia dengan kehilangan $\geq 3$ gigi posterior mengalami gangguan, keterbatasan dan rasa sakit.

\section{DAFTAR PUSTAKA}

1. Umami Riza, Priyanto Sigit. Hubungan Kualitas Tidur dengan Fungsi Kognitif dan Tekanan darah pada Lansia di Desa Pasuruhan Kecamatan Mertoyudan Kabupaten Magelang. Jurnal Fakultas IImu Kesehatan, (2013)

2. Setiawan GW. Pengaruh Senam Bugar Lanjut Usia (Lansia) terhadap Kualitas Hidup Penderita Hipertensi. ejournal.unsrat.ac.id, Vol.1, no. 2 (2013). Diunduh pada Maret 2014

3. Amurwaningsih Musri, Darjono Uswatun Nisaa' Arum. Analisis hubungan Kualitas Hidup yang Berhubungan dengan Kesehatan Mulut (OHRQoL) dan Status Kecemasan dengan Status Nutrisi pada Masyarakat Usia Lanjut. http://www.jurnal.unissula.ac.id, vol.48, no.123 (2010). Diunduh Maret 2014

4. Sutikno E. Hubungan antara Fungsi Keluarga terhadap Kualitas Hidup Lansia. Institut IImu Kesehatan Bhakti Wiyata Kediri. Jurnal Kedokteran Indonesia, vol.2, no.1 (2011)
5. Bandiyah, S. Lanjut Usia dan Keperawatan Gerontik. Dalam: Setiawan A. Lanjut Usia dan Keperawatan Gerontik. Yogyakarta: Nuha Medika, hal.3,13,64 (2009)

6. Chandra Satish, Chandra Shaleen, Chandra Mithilesh, Chandra Nidhee. Textbook of Dental amd Oral Histology with Embryology and Multiple Choice Questions. New Delhi: Jaypee Brothers Medical Publishers, hal.274 (2004)

7. Sugiaman Dina H, Himawan Laura S, Fardaniah Sitti. Relationship of Occlusal Schemes with the Occurrence of Temporomandibular Disorders. Journal of Dentistry Indonesia, vol.18, no.3, 63-7 (2011)

8. Thio Trifena L. M., Mintjelungan Christy N., Hutagalung Bernat SP. Pola Kehilangan Gigi Dan Kebutuhan Perawatan Gigi Tiruan Sebagian Lepasan Dikelurahan Meras Kecamatan Bunaken. http:// ejournal.unsrat.ac.id, vol.2, no.1 (2014). Diunduh April 2014

9. Gotfredsen K, Walls AWG. What Dentition Assure Oral Function?. Clinical Oral Implant Research, vol.18 (2008)

10. Kurniawan Aji, Wimardhani Yuniardini Septorini, Rahmayanti Febrina. Oral Health and Salivary profiles of Geriatric Outpatients in Cipto Mangunkusumo General Hospital. Indonesian Journal of Dentistry, vol.17, no.2, hal.53-7 (2010)

11. Kida IA, Åstrøm AN, Strand GV, and Masalu JR. Clinical and Socio-behavioral Correlated of Tooth loss: a Study of Older Adults in Tanzania. BMC Oral Health, vol.6, hal.5 (2006)

12. Bahjuri Ali P, Hadiat, Subekti Imam, Diani Tresna Yosi, Sularsono, Wikanestri Inti. Pembangunan Kesehatan dan Gizi di Indonesia: Overview dan Arah ke Depan. Jakarta: BAPPENAS, hal.9 (2009)

13. Destarina Vera, Agrina, Irvani Dewi Yulia. Gambaran Spiritualitas Lansia di Panti Sosial Tresna Werdha Khusnul Khotimah Pekanbaru. JOM PSIK. Vol.1, No.2 (2014)

14. Arigbede, Dosmu, Shaba, Esan. Evaluation of Speech in Patients with Partial Surgically Acquired Defects: Pre and Post Prosthetic Obturation. The Journal of Contemporary Dental Practice, vol.7, no.1 (2008)

15. Saintrain MVL, Souza EHA. Impact of tooth loss on the quality of life of elderly people. The Gerodontology Society and John Wiley \& Sons A/S. Vol. 29, Issue 2, hal.e632-6 (2012)

16. Wang $M Q$, Xue F, He JJ, Chen JH, Chen CS, Raustia A. Missing Posterior Teeth and Risk of Temporomandibular Disorders. JDR. vol.88, no.10 942-5 (2009)

17. Bansal M, Singh S, Jindal R. Concept of Shortened Dental Arch: An Overview. Indian Journal of Multidisciplinary Dentistry. Vol.2, Issue 4 (2014)

18. Naini FB, Gill DS. Facial Aesthetics: 2. Clinical Assessment. Dent Update. 35 hal. 159-70 (2008)

19. Kaunang WPJ, Supit A, Angraeni A. Presepsi Masyarakat terhadap Pembuatan Gigi Tiruan oleh Tukang Gigi di Desa Treman Kecamatan Kauditan. 
ejournal.unsrat.ac.id, vol.1, no.2 (2013)

20. Montero-Martín J, Bravo-Pérez M, AlbaladejoMartínez A, Hernández-Martín LA. Validation the Oral Health Impact Profile (OHIP-14sp) for adults in Spain. Med Oral Patol Oral Cir Bucal. 1;14 (1):E44-50 (2009)

21. Pushpanjali K, Mohan M, Renuka P. Assessing impact of oral diseases on oral health related quality of life of institutionalized elderly using OHIP-14 in Bengaluru: A cross sectional study. IOSR Journal of Dental and Medical Science. Vol.6, Issue 6 (2013)

22. Walter MH, Weber A, Marre B, Gitt I, Gerss J, Hannakk W. In Individuals with Loss of Molar Support, the Treatment Based on Shortened Dental Arch Concept may not Decrease the Risk of Tooth Loss Compared with Molar Repleacement with Removable Partial Prosthesis. J Dent Res. 89:818-22 (2010)

23. Gerritsen AE, Allen PF, Witter DJ, Bronkhorst EM, Creugers NHJ. Tooth Loss and Oral Health-Related Quality of Life: a Systemic review and meta-analysis. Health and Quality of Life Outcomes, 8:126 (2010) 